\title{
Analysis and Design of a Hybrid Renewable Energy System - Lebanon Case
}

\author{
Marc Anthony Mannah, Ali Koubayssi, Ahmad Haddad, Baraa Salami, \\ (Department of Electrical and Electronics Engineering, Lebanese International University, Lebanon,)
}

\begin{abstract}
The depletion of fossil fuels and their environmental consequences have prompted searching for other sources of energy aiming to global status amelioration. In the recent past, renewable energy sources have been considered as alternatives for the fossil fuel energy sources. The unexpected pattern of natural resources assesses integrated utilization of these sources to provide persistent and reliable power supply to the consumers. The technology's advantages, requirements and related improvements are underlined and results are generalized. This paper covers the design of a solar and wind based hybrid renewable system presenting calculations and considerations in order to achieve an optimized design. Since hybrid systems performance relies mainly on geographical and meteorological aspects, the study will consider the case of the Mediterranean area and in particu lar Lebanon.

Keywords: Wind energy, Solar energy, Hybridization, Optimu m Design Requirement, Return on Investment
\end{abstract}

\section{INTRODUCTION}

With the population and energy need increase around the world, power production was forced to be raised. Our action today in producing power is to use fossil fuels as a central source of energy. These resources are non-renewable, so they are subject to depletion. Fossil fuels based generation emits harmful gases that have a major effect in increasing the global warming. Therefore, the need for searching for alternative energy source that conserves the environment and save people is a must. Renewable energy is proven to be the ultimate solution. It has a lot of environmental benefits and lessens global warming by reducing the emission of toxic gases, that is, beside its socio-economic benefits. However, renewable energy sources used solely do not provide continuous and reliable power, thus, the ultimate solution is to use them in a combined way, forming what is known by a hybrid generating system.

The first solar power system was developed in 1860 in France to produce steam to drive machinery whereas the first windmill was developed in 1888 in Cleveland, Ohio for electrical generation [1]. These systems were simple and small and it is until 1990 when the actual development started [2]. The high hazard correlating with fossil fuels supply and safety have accelerated the renewable energy growth in an exponential way. Nowadays renewable technologies supply about $19.1 \%$ of the world's total energy needs and $23.7 \%$ of global electricity [3]. Renewable energy is continuing to grow against the increasing global energy consumption and the slight fall of fossil fuels. Regardless of the rise in energy needs, the carbon emission remained constant in 2014 with the global economic growth. This stabilization is associated with the rising penetration of renewable energy.

The paper is divided as follows: Section II discusses solar and wind renewable energies in general and shows the require ments of hybridization. Section III reflects the hybridization principles that are based on a real implemented system in Lebanon. Section IV represents the different steps in designing the project. Section V presents a preliminary design along with its calculations. Section VI discusses the possibilities of improving the design and presents an optimum design using HOMER software. Simulation results are detailed in section VII. Finally, section VIII ends with a summarizing conclusion and highlights the results as well as the potential improvements.

\section{WIND / SOLAR RENEWAB LE ENERGIES}

Wind energy distribution is not uniform and changes function of geographical aspects. The regional patterns of dissipation affect the availability of wind sources. The estimated wind power source is currently estimated to around 2470 EJ [4]. The wind power varies geographically due to many factors. The most important factor is the height. Places of higher altitudes have more wind due to various atmospheric factors. Besides, at higher places there is less obstruction from the surrounding hills, trees and building. In fact the height is so important that alternative energy scientists and engineers are trying to use kites (due to the heights they can easily reach) to tap the wind power [5].

Solar energy power depends on the available radiation. The available energy at the surface of the sun is approximately $60,000 \mathrm{kWh} / \mathrm{m}^{2}$, while the total radiation reached to the surface of the 
atmosphere is only $1.4 \mathrm{kWh} / \mathrm{m}^{2}$, representing around 80 trillion $\mathrm{kW}$ [6]. This amount of radiation represents 13,000 times the present world energy use. Solar energy is by far the largest energy resource on Earth. About $47 \%$ of all incident solar energy is reaching the top of the atmosphere. Due to the properties of the atmospheric gases, only $51 \%$ of the solar intensity on the top of the atmosphere reaches to the ground whether in a direct or unscattered way [6]. This represents $89 \mathrm{PW}$ of the energy received by the earth surface. From this huge amount of energy, only less than $0.02 \%$ is sufficient to replace the conventional energy used in the whole world [7]. Therefore one can realize the tremendous potential of solar energy in addition to its significant benefits on the environment, human health, economics and so on. The current installed PV capacity is somewhat limited compared to other renewable energy sources. However, PV technical potential is considered high compared to other renewable energy sources for a per unit area. This latter depends on the available area, the solar irradiation, and solar PV efficiency. Till now, the PV efficiency for the used solar cells is limited to $23 \%$. This efficiency is limited by the laws of physics. Solar yearly energy density varies between 2000 $\mathrm{kWh} / \mathrm{m}^{2}$ and $3200 \mathrm{kWh} / \mathrm{m}^{2}$ in the South Mediterranean region [8]. In Lebanon, the average yearly solar irradiance can reach $2939 \mathrm{kWh} / \mathrm{m}^{2}$ at 0 degree inclination [9].

\section{HYBRIDIZATION}

This section begins with the typical configuration of an ON grid hybrid system as shown in Fig. 1. We note the wind turbine, solar panel, main supply, the backup generator, storage system, power electronics (inverter and converter), the energy management system (controllers) as well as the load. Generally the main control system has many functions including the following: ensuring the continuity of energy to the load, evaluating the excess of energy and monitoring the smooth operation of all components of the system. In most cases, a hybrid system requires power control techniques leading to mounting of AC-DC or DC-DC converters in both wind and solar power generation systems.

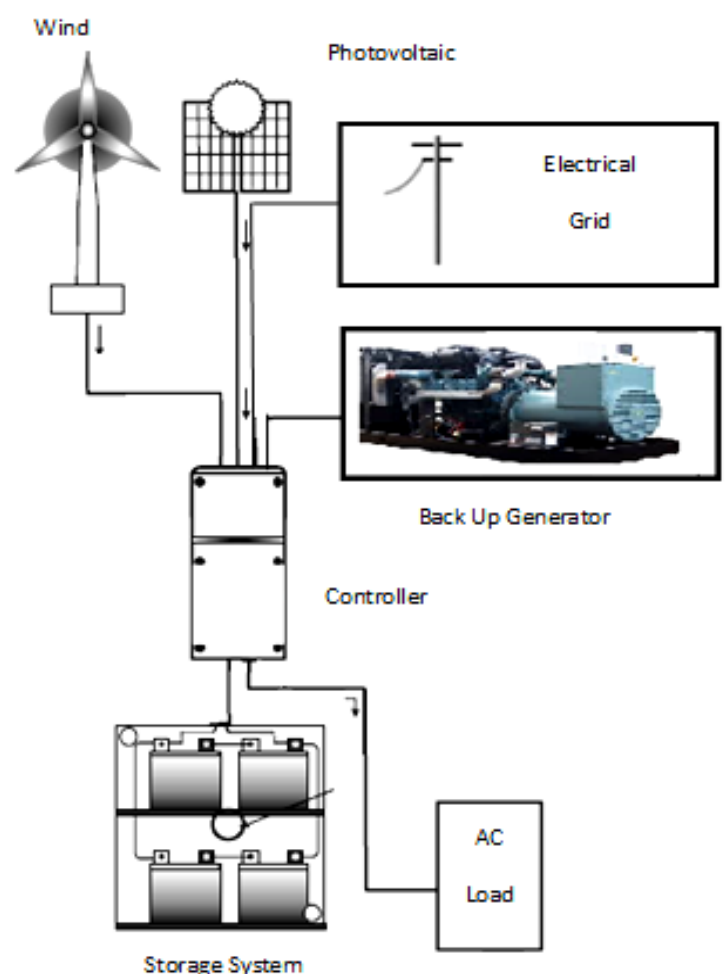

Fig. 1. Typical grid connected hybrid wind-solar system with backup generator.

The two systems may be interconnected in parallel at the output of the converters and connected to a storage battery. Each DC-DC converter can control the battery charging for load supplying. In the case of installing converters and batteries at a centralized location, storage batteries are mostly installed near the wind and solar power generation systems, so this will restrict the freedom of installing batteries on flat ground or in places easy to be accessed for maintenance and replacement [10]. Fig 2 shows the block diagram model of this system including the various sources, converters, controllers and loads.

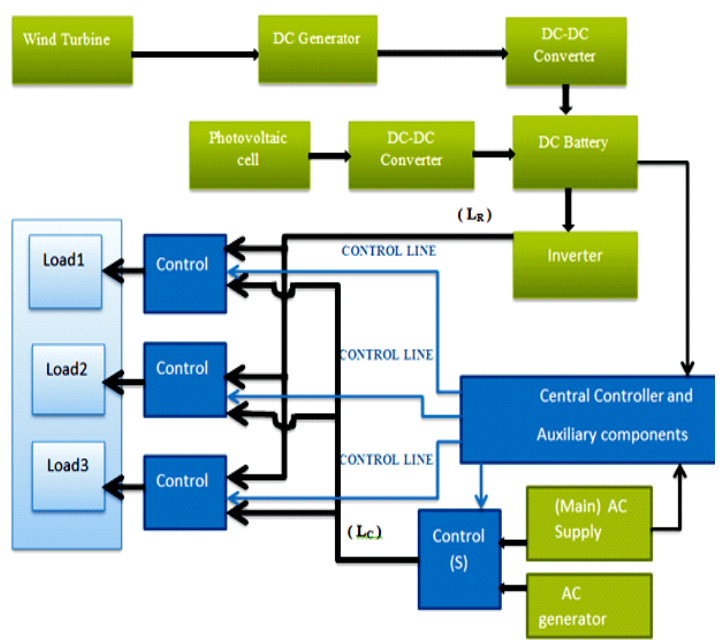

Fig. 2. Block diagram model of a typical hybrid power system. 


\section{HYBRID SYSTEM DESIGN}

This section focuses on designing the different components of the system. The study starts by specifying the load demand followed up by sizing all components. A financial study underlining the return on investment is also carried out. The project discussed in this paper consists of a typical four rooms' house located in South of Lebanon at a 400 meter altitude. The location matters as it affects the efficiency of both solar and wind captured energies.

\section{A. Load Demand}

In general, the typical rating demand of such houses is around $4 \mathrm{~kW}$. A study covering all electrical equipments, their power ratings, the average working hours per day and their quantities has been carried out. Such study allows calculating the total energy consumed and the total power delivered. Table I shows the maximum load demand in Wh/day of the system under study. For such typical residential load, an approximated $14 \mathrm{kWh}$ /day consumption is noted. This calculation is necessary in order to be able to size the various components.

\section{B. Components Design}

There are many components that have been designed for this hybrid system. This part will mention only the basic outcomes.

\section{1) PV Array Design}

In designing the PV module, first we should calculate the required array output per day; it can be obtained by dividing the total energy demand per day $(14.42 \mathrm{kWh} /$ day) by the inverter efficiency (typically $85 \%$ ) [11], leading to a required array output of 16.97 $\mathrm{kWh}$ /day. For the selected PV module, the guaranteed output power is obtained from the manufacturer's datasheet. The nominal maximum output power at STC is $200 \mathrm{~W}$. The power tolerance is $3 \%$ and the guaranteed output power is $97 \%$ of the maximum output power, or 194 watts [12]. The number of peak sun hours is identical to the average daily solar insolation over $1 \mathrm{~kW} / \mathrm{m}^{2}$ [13]. From the HOMER data for the design location and optimum array tilt, the worst peak sun hour for south Lebanese located house is in December and equals to 2.41 hours. Table II shows all the required parameters needed for the design of PV panels.

Table I Average load demand for a typical Lebanese house

\begin{tabular}{|l|l|l|l|l|}
\hline $\begin{array}{l}\text { Appliance } \\
\text { s }\end{array}$ & $\begin{array}{l}\text { Typical } \\
\text { Power } \\
\text { (W) }\end{array}$ & $\begin{array}{l}\text { Working } \\
\text { hrs./day }\end{array}$ & Qty & $\begin{array}{l}\text { Energ } \\
\mathbf{y} \\
(\mathbf{W h} / \mathbf{d} \\
\text { ay })\end{array}$ \\
\hline TV & 150 & 5 & 3 & 2,250 \\
\hline $\begin{array}{l}\text { Water } \\
\text { heater }\end{array}$ & 500 & 2 & 1 & 1,000 \\
\hline
\end{tabular}

\begin{tabular}{|l|l|l|l|l|}
\hline $\begin{array}{l}\text { Satellite } \\
\text { receiver }\end{array}$ & 8 & 5 & 3 & 120 \\
\hline $\begin{array}{l}\text { Hair } \\
\text { dryer }\end{array}$ & 350 & 0.10 & 1 & 35 \\
\hline $\begin{array}{l}\text { Bread } \\
\text { oven }\end{array}$ & 1,000 & 0.10 & 1 & 100 \\
\hline $\begin{array}{l}\text { Microwav } \\
\text { e }\end{array}$ & 1,400 & 0.15 & 1 & 210 \\
\hline $\begin{array}{l}\text { Refrigerat } \\
\text { or }\end{array}$ & 650 & 8 & 1 & 5,200 \\
\hline AC & 1,500 & 2 & 1 & 3,000 \\
\hline $\begin{array}{l}\text { Wi-Fi } \\
\text { router }\end{array}$ & 10 & 24 & 1 & 240 \\
\hline $\begin{array}{l}\text { Telephone } \\
\text { handy }\end{array}$ & 3 & 24 & 1 & 78 \\
\hline $\begin{array}{l}\text { Mobile } \\
\text { charger }\end{array}$ & 3 & 2 & 3 & 18 \\
\hline $\begin{array}{l}\text { washing } \\
\text { machine }\end{array}$ & 350 & 0.50 & 1 & 175 \\
\hline laptop & 100 & 2 & 1 & 200 \\
\hline fan & 60 & 3 & 3 & 540 \\
\hline iron & 1,200 & 0.10 & 1 & 120 \\
\hline Lights & 20 & 8 & 6 & 960 \\
\hline $\begin{array}{l}\text { Water } \\
\text { pump }\end{array}$ & 500 & 0.10 & 1 & 50 \\
\hline $\begin{array}{l}\text { Vacuum } \\
\text { cleaner }\end{array}$ & 1,250 & 0.10 & 1 & 125 \\
\hline & & & Total & 14,421 \\
\hline
\end{tabular}

Table II Parameters of the designed PV system

\begin{tabular}{|l|l|}
\hline Parameters & Results \\
\hline Energy Output of Module (Wh) & 465.6 \\
\hline $\begin{array}{l}\text { Energy Output at operating } \\
\text { Temperature (Wh) }\end{array}$ & 419.04 \\
\hline Number of Required Modules & 41 \\
\hline Number of Modules perString & 3 \\
\hline Number of String in Parallel & 14 \\
\hline Total Number of Modules purchased & 42 \\
\hline Nominal Rated Array Output (W) & 8400 \\
\hline
\end{tabular}

\section{2) Wind Turbine Design}

The selection of the wind turbine depends on the load size $(4 \mathrm{~kW})$ and the wind speed that depends on the location (5 to $5.5 \mathrm{~m} / \mathrm{s}$ ) [14]. Therefore, the design has to account for a wind turbine that gives $4 \mathrm{~kW}$ at a wind speed of $5 \mathrm{~m} / \mathrm{s}$. Accordingly, the selected system is a $20 \mathrm{~kW}$ wind generator based wind turbine. The output power versus the wind speed curve is thoroughly explained in [15]. This latter provides more than $4 \mathrm{~kW}$ at this speed range, thus satisfying the load demand.

\section{3) Battery Design}

The storage battery bank is sized to meet the load demand during the absence of the renewable energy sources. It should also have days of autonomy, which is normally taken to be 2 or 3 days [16]. We will assume in this case study that the storage will be for only one day or 20 hours (according to the battery specifications) due to the presence of multiple sources of power. The most 
common battery type used in such applications is the lead acid deep cycle batteries. These batteries are specifically designed to be discharged to low energy level and rapidly recharged and discharged day after day for years [17]. Thus, we will take into consideration the use of lead acid batteries with $80 \%$ depth of discharge and $48 \mathrm{~V}$ battery bank voltage. The minimum ampere hour capacity required for the battery can be calculated according to (1).

$\mathrm{C}_{\mathrm{B}}=\frac{\mathrm{E}_{\mathrm{L}} \mathrm{S}_{\mathrm{D}}}{\mathrm{V}_{\mathrm{B}} \mathrm{DOD}}$

Note that $\mathrm{E}_{\mathrm{L}}$ is the load demand in $\mathrm{Wh}, \mathrm{S}_{\mathrm{D}}$ is the battery autonomy or storage days; $V_{B}$ is the battery bank voltage; and DOD is the battery depth of discharge [16]. The selected battery has storage of 20 hours with a capacity 140 Ah. Hence, with 14.42 $\mathrm{kWh}$ /day load energy consumption, the required battery capacity will be 312.96 Ah. Further parameters are listed in table III. The total $\mathrm{Ah}$ demand per day and the total battery Ah capacity are needed to calculate the actual daily DOD [12].

Table III Parameters of the designed battery system

\begin{tabular}{|l|l|}
\hline Parameters & Results \\
\hline Number of the Parallel Batteries & 3 \\
\hline Number of Series Batteries in Each String & 4 \\
\hline Total Number of Batteries & 12 \\
\hline Total Amp-Hour Capacity & 420 \\
\hline Total kWh Capacity & 20.16 \\
\hline
\end{tabular}

\section{4) Controller Design}

The controller gives orders to turn On/Off any source according to a predefined logic. It senses some inputs and according to the setting, it orders an output, in order to satisfy the user need. In this system, the controller will sense the power from the two main renewable sources of energies, the battery bank, the back-up generator and the state of the load demand. Following that, the control unit compares the inputs and orders to switch (On/Off) the different power sources. The logic of the controller is divided into many scenarios, as shown below in Table IV.

Table IV Controller various scenarios

\begin{tabular}{|c|c|}
\hline 1 & $\begin{array}{l}\text { If } P_{\text {wind }} \text { and } P_{\text {solar }} \text { are both sufficient, only } \\
\text { solar feeds the load. }\end{array}$ \\
\hline 2 & $\begin{array}{l}\text { If } P_{\text {wind }} \text { is larger than } P_{\text {laod }} \text {, then the wind } \\
\text { turbine is only switched on. After that the } \\
\text { controller checks if there is an excess in power, } \\
\text { then it checks the status of batteries. If they are } \\
\text { not fully charged, then it charges them. }\end{array}$ \\
\hline 3 & $\begin{array}{l}\text { If } P_{\text {solar }} \text { is greater than } P_{\text {laod }}, \text { then it switches on } \\
\text { the solar panels only. After that it checks if there } \\
\text { is an excess in power, checks the status of } \\
\text { batteries and if not fully charged, it charges them. }\end{array}$ \\
\hline 4 & $\begin{array}{l}\text { If } P_{\text {wind }} \text { and } P_{\text {solay }} \text { are less than } P_{\text {laod }}, \text { but their } \\
\text { sum combined is greater than the load, then it } \\
\text { connects both wind turbine and solar panels. If } \\
\text { there is still an excess in power, and the batteries }\end{array}$ \\
\hline
\end{tabular}

\begin{tabular}{|l|l|}
\hline & are not fully charged, then it charges them. \\
\hline $\mathbf{5}$ & $\begin{array}{l}\text { If } P_{\text {wind }}+P_{\text {solay }} \text { are less than the load, then it } \\
\text { directly connects the battery bank. }\end{array}$ \\
\hline $\mathbf{6}$ & $\begin{array}{l}\text { If the battery bank is insufficient, then the back- } \\
\text { up generator is turned on in order to charge the } \\
\text { batteries. }\end{array}$ \\
\hline
\end{tabular}

\section{Return on Investment}

The ROI (return on investment) of renewable systems is becoming more appealing and popular every day. When considering upgrades to a home, ROI is a sound way to determine when and where to invest. To calculate the ROI, we should consider the home's location, sun insolation, type of installation and current available encouragements, as well as financing terms [18].

First of all we should calculate the annual electricity expense. In Lebanon, there is an outage in the electricity supply from the official supplier 'Electricite du Liban' (EDL); thus, a backup generator's expense has to be taken into account. For the considered location (south of Lebanon), the electricity is available only 8 hours per day, and the power supply for the remaining 16 hours is provided by the backup generator. Starting with EDL, we can expect the daily energy consumption from it by dividing the 8 hours over 24 hours and then multiplying by the total energy demand per day $(14.421 \mathrm{kWh} /$ day); so the average energy supply from EDL will be $4.807 \mathrm{kWh} /$ day or 144.21 $\mathrm{kWh} /$ month. For the total amount of the electrical bill of the EDL, the reader may refer to [19]. Many parameters contribute to this latter, namely, the subscription fee, the rehabilitation tax, the electricity cost (which is 13 cents/kWh in Lebanon) and other minor costs. Calculations for our case study lead to an estimated averaged bill of $349.54 \mathrm{USD} /$ year. The energy consumption from generators is obtained by considering the number of operating hours and the total energy demand per day, leading to 9.614 $\mathrm{kWh} /$ day or $288.42 \mathrm{kWh} /$ month. The generator's energy price in Lebanon is 47 cents/kWh. Thus, the energy price resulting from the use of the backup generator is approximated to $1616 \mathrm{USD} / y e a r$. Therefore, the total amount paid for electricity in our case study project is about 1965 USD/year.

In order to be able to calculate the ROI, the overall cost of implementation and maintenance of the hybrid system needs to be calculated. This latter depends on the choice and the sizing of the elements. The cost of the preliminary sizing previously presented will be presented in the next section.

\section{PRELIMINARY DESIGN}

According to the preliminary design, the different components were sized and their cost was calculated based on a market survey and the availability of the various components. The overall 
cost is shown below in Table V. These components and their characteristics are introduced to HOMER software in order to know the percentage of renewable participation in supplying the load.

Table V System components' prices (Preliminary

\begin{tabular}{|l|l|l|l|}
\hline Component & Qty & $\begin{array}{l}\text { Price/Component } \\
\text { (USD) }\end{array}$ & $\begin{array}{l}\text { Price } \\
\text { (USD) }\end{array}$ \\
\hline PV panels & 42 & 250 & 10,500 \\
\hline $\begin{array}{l}\text { Wind } \\
\text { turbine }\end{array}$ & 1 & 13,580 & 13,580 \\
\hline Batteries & 12 & 250 & 3,000 \\
\hline Inverter & 1 & 950 & 950 \\
\hline Generator & 1 & 2,200 & 2,200 \\
\hline Converter & 1 & 226 & 226 \\
\hline & & Total Price & 30,456 \\
\hline & & &
\end{tabular}

The solar and wind energy resources supply about $99.84 \%$ of the total energy demand, thus leading to a total annual savings will be of 1961.55 USD/year. The ROI is then obtained by dividing the total cost of our system by the annual savings; leading to a payback period of 15.5 years [18]. Accounting for 1 year cost of maintenance to every 5 years of operation [18], the ROI is finally estimated to 20 years. From this point on, and accounting for the associated maintenance cost, the user shall economize around 1570 USD per year. Note that at this stage, HOMER software was only used to depict the percentage of participation of the various sources. The above numbers present the ROI based on a preliminary modeling, but not necessary an optimum one. In order to account for all influencing parameters and to obtain an optimum design, simulations will be fully carried out next using the HOMER software. This latter will allow to define the optimal parameters for a better and more economical design.

\section{OPTIMUM DESIGN}

Hybrid Optimization Model for Electric Renewables (HOMER) provides highly sensitive analys is of hybrid systems and accounts for the location specific characteristics. The needed inputs for analysis are the solar insolation, wind speed, temperature data, load profile, particular constraints, system control and economic factors [20]. In this section the prices of the components with different sizes are considered in order to reach the optimum design.

\section{1) PV Array Design}

The cost of one 200 watt PV panel is approximated to 250 USD. The installation and maintenance costs are approximated respectively to 1000 USD and 10 USD/year. Four different configurations are considered for our system and inserted into HOMER. The sizes are 0 (no PV modules), 2.8, 5.6, $8.4 \mathrm{~kW}$. Note that no tracking system is included in the PV system.

\section{2) Wind Turbine Design}

Availability of energy from wind turbine depends greatly on wind speed variations. Therefore, wind turbine rating is generally much higher compared to the peak load demand (which is 3.06 $\mathrm{kWp}$ according to HOMER). In this analysis, wind turbine of FD5-5000 model is considered. It has a rated capacity of $5 \mathrm{~kW}$ and provides a $240 \mathrm{~V}$ AC output. The cost of one unit is considered to be 4,612 USD while replacement and maintenance costs are taken as 3,699 USD and 47 USD/year respectively [21]. Different units are given $(0,1$ or 2 units) to allow the simulation program find the optimum solution. Lifetime of a turbine is taken to be 20 years.

\section{3) Power Inverter Design}

The estimated capital and replacement costs of an inverter are approximated to 950 USD. A lifetime of 15 years was assumed in which the inverter efficiency was assumed to be $95 \%$, for all considered sizes [22]. Inverters of various sizes ranging from 0 to $4 \mathrm{~kW}$ are considered in the analysis. The choice of this range is justified by the fact that all renewable sources are meant to be of lower rating in the optimized design.

\section{4) Battery Bank Design}

When the total outputs of the PV array and wind turbine are more than the energy demand, the battery bank is charged. We will assume that the properties of the battery remain constant throughout its lifetime and are not affected by external factors such as temperature [23]. The selected batteries in our study have a nominal voltage of $12 \mathrm{~V}$ with a rated capacity of $140 \mathrm{Ah}$. Every 4 lead-acid batteries are connected in series forming a string capable of producing $6.72 \mathrm{kWh}$ of electricity. The estimated price of each battery replacement is 250 USD. The life expectancy of each battery usually varies between 2 and 6 years [24] and will be assumed in our study to 5 years. Different numbers of battery strings $(0,1,2$, and 3$)$ were considered in this analysis.

\section{5) Diesel Generator}

A 5kVA generator is used as a backup power supply. Its cost is estimated to 2,200 USD. The present cost of diesel is $0.38 \$ / \mathrm{L}$ and it may vary around this value. The operation over maintenance cost is estimated to $0.082 \$ / \mathrm{hr}$ [24-25].

\section{SIMULATION RESULTS}

The load profile (typical Lebanese house) was introduced into our simulation. The meteorological data for a one year period including 
the hourly solar radiation and the wind speed were introduced as well in order to calculate the monthly average values of clearness index (5.32 $\mathrm{kWh} / \mathrm{m}^{2} /$ day $)$, the daily radiation $(0.61 \mathrm{kWh} / \mathrm{m} 2)$ and daily wind speed $(5.41 \mathrm{~m} / \mathrm{s})$. The results are exhibited in a complete form in which the system configurations are listed according to their net present cost NPC. Fig. 3 shows the list of possible combinations of the system components. Parameters such as the operational characteristics, annual electrical energy production, served annual electrical loads, excess of electricity, RE fraction, capacity shortage, and so forth can be evaluated. The optimal energy system includes a $2.8 \mathrm{~kW}$ PV module (14 PV panels), one wind turbine (rated $5 \mathrm{~kW}$ ), $4 \mathrm{~kW}$ diesel generator, $4 \mathrm{~kW}$ inverter and 4 batteries (140 Ah each). The cost of energy (COE) would be then 0.307 $\mathrm{USD} / \mathrm{kWh}$, whereas the initial capital required and NPC are respectively 12,262 USD and 20,909 USD. This could be considered as a good choice for the system operation especially that the participation in energy production made by renewable resources is relatively high. Furthermore, simulation results show that this system has a total annual electrical energy production of $14,812 \mathrm{kWh} / \mathrm{yr}$ and the total energy produced from the wind turbine is higher than the energy generated from the PV array.

\begin{tabular}{|c|c|c|c|c|c|c|c|c|c|c|}
\hline \multicolumn{5}{|c|}{ Architecture } & \multicolumn{4}{|c|}{ Cost } & \multicolumn{2}{|c|}{ System } \\
\hline${ }_{(\mathrm{PW})}^{\mathrm{PV}} \mathrm{\nabla}$ & WT 8 & $\begin{array}{l}\text { GenAkW } \\
(\mathrm{kW})\end{array}$ & $\begin{array}{l}140 \mathrm{Ah} \\
\text { battery }\end{array}$ & ${ }_{(\mathrm{kW})}^{\text {Inverter }} \nabla$ & ${ }_{(S)}^{C O E} \nabla$ & ${ }_{(\$)}^{N P C} \nabla$ & $\begin{array}{c}\text { Operating } \\
\text { cost } \\
(5)\end{array}$ & $?_{(\$)}^{\text {Initial capital }} \nabla$ & $\begin{array}{c}\operatorname{Ren} F \text { Frac } \\
(\%)\end{array}$ & $\begin{array}{l}\text { Cap! } \\
\text { (kWt }\end{array}$ \\
\hline \multirow[t]{2}{*}{2.80} & 1 & 4.00 & 4 & 4.00 & $\$ 0.307$ & $\$ 20,909$ & $\$ 668.85$ & $\$ 12,262$ & 68 & 0 \\
\hline & & 4.00 & 4 & 4.00 & $\$ 0.355$ & $\$ 24,127$ & $\$ 1,545$ & $\$ 4,150$ & 0.0 & 0 \\
\hline 2.80 & 1 & 4.00 & & 4.00 & $\$ 0.412$ & $\$ 28,053$ & $\$ 1,299$ & $\$ 11,262$ & 15 & 0 \\
\hline \multirow[t]{3}{*}{280} & & 4.00 & & 4.00 & $\$ 0.421$ & $\$ 28,676$ & $\$ 1,704$ & $\$ 6,650$ & 0.0 & 0 \\
\hline & 1 & 4.00 & & & $\$ 0.437$ & $\$ 29,757$ & $\$ 1,775$ & $\$ 6,812$ & 0.0 & 0 \\
\hline & & 4.00 & & & $\$ 0.479$ & $\$ 32.601$ & $\$ 2,352$ & $\$ 2.200$ & 0.0 & 0 \\
\hline
\end{tabular}

Fig. 3. Overall optimized results according to NPC

All results related to both the electric energy production and consumption is summarized in Table VI. In addition, the share of PV array, wind turbine and diesel generator for electrical production in each month of the year are shown in Fig. 4. The a mount of electricity production is ranged from $1.4 \mathrm{~kW}$ in November to almost $1.85 \mathrm{~kW}$ in August.

Table VI Electrical production / demand for PVWind systems

\begin{tabular}{|l|l|}
\hline $\begin{array}{l}\text { Annual electric PV array } \\
\text { production }\end{array}$ & $\begin{array}{l}5,926 \mathrm{kWh} / \mathrm{yr} . \\
(40.01 \%)\end{array}$ \\
\hline $\begin{array}{l}\text { Annual electric wind } \\
\text { production }\end{array}$ & $\begin{array}{l}7,200 \mathrm{kWh} / \mathrm{yr} . \\
(48.61 \%)\end{array}$ \\
\hline $\begin{array}{l}\text { Annual electric generator } \\
\text { production }\end{array}$ & $\begin{array}{l}1,686 \mathrm{kWh} / \mathrm{yr} . \\
(11.38 \%)\end{array}$ \\
\hline $\begin{array}{l}\text { Annual electric total } \\
\text { production }\end{array}$ & $14,812 \mathrm{kWh} / \mathrm{yr}$. \\
\hline $\begin{array}{l}\text { Annual electric consumption } \\
\text { (AC load) }\end{array}$ & $\begin{array}{l}5,263 \quad \mathrm{kWh} / \mathrm{yr} . \\
(100 \%)\end{array}$ \\
\hline
\end{tabular}

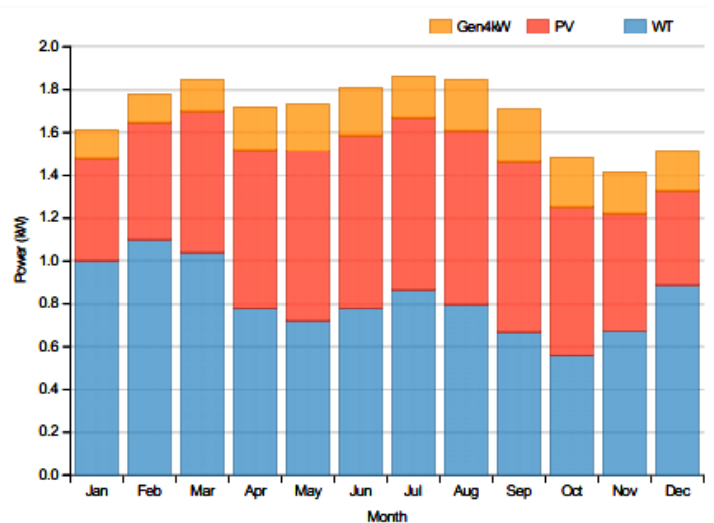

Fig. 4. Contribution of the power units

We note that the yearly cost saving of this system is $16.8 \%$ with respect to the initial investment as shown in Fig 5and 6. Furthermore, the system payback is about 6-7 years which makes it a good applicable system with tolerable present and annual worth of 11,694 \$ and 1,095 \$ respectively. The ROI is considerably improved compared with the preliminary design.

\begin{tabular}{|c|c|c|c|c|c|c|}
\hline Component & Capital (\$) & Replacement (\$) & O\&M (\$) & Fuel (\$) & Salvage (\$) & Total $(\$)$ \\
\hline Suntech PV & $\$ 3,500,00$ & $\$ 0.00$ & $\$ 361.97$ & $\$ 0.00$ & $\$ 0.00$ & $\$ 3,862,00$ \\
\hline WT $5 \mathrm{~kW}$ & $\$ 4,612.00$ & $\$ 1,179,30$ & $\$ 607.59$ & $\$ 0.00$ & (\$5664.59) & $\$ 5,734,30$ \\
\hline $4 k W$ Kipor & $\$ 2,200,00$ & $\$ 0.00$ & $\$ 1,274,20$ & $\$ 3,501.80$ & $\$ 0.00$ & $\$ 6,976,00$ \\
\hline Leoch 140 Ah Lead Acid & $\$ 1,000,00$ & $\$ 2,059.10$ & $\$ 0.00$ & $\$ 0.00$ & $\$ 0.00$ & $\$ 3,059,10$ \\
\hline Converter & $\$ 950.00$ & $\$ 403.06$ & $\$ 0.00$ & $\$ 0.00$ & (\$75.86) & $\$ 1,277,20$ \\
\hline System & $\$ 12,262,00$ & $\$ 3,641.50$ & $\$ 2,243,80$ & $\$ 3,501,80$ & $(\$ 740.45)$ & $\$ 20,909,00$ \\
\hline
\end{tabular}

Fig. 5. Total NPC of the proposed system components - 25 years

\begin{tabular}{|l|l|}
\hline \multicolumn{1}{|c|}{ Metric } & \multicolumn{1}{c|}{ Value } \\
\hline Present worth (\$) & $\$ 11,694$ \\
\hline Annual worth (\$/yr) & $\$ 1,095$ \\
\hline Return on investment (\%) & 16.8 \\
\hline Internal rate of return (\%) & 16.9 \\
\hline Simple payback (yr) & 5.80 \\
\hline Discounted payback (yr) & 7.10 \\
\hline
\end{tabular}

Fig. 6. Economic factors of current system vs. base system

\section{CONCLUSION AND PERSPECTIVES}

This paper deals with the design and analysis of a solar wind hybrid system. First, a preliminary design underlining all necessary challenges and calculations is presented. This design is then improved and optimized. Simulation results seem to be promising with a $33 \%$ decreases in the overall cost of the system as well as a notable improvement in the ROI. The current design can be further improved by including more advanced 
control techniques. More accurate design and financial studies should be carried out in various areas and markets and for various loads in order to present generalized numbers that can be adopted as official references.

\section{REFERENCES}

[1]. J. Vestergaard, L. Brandstrup, and R. Goddard, A Brief History of the Wind Turbine Industries in Denmark and the United States, Academy of International Business Conference Proceedings, Savannah, USA, 2004, 322-327.

[2]. P. Chefurka, World Energy to 2050, Global energy, 2007.

[3]. A. Zervos, Renewables 2016, REN21 France, Global Status Report, 2016.

[4]. X. Lu, M. McElroy and J. Kiviluoma, Global potential for wind-generated electricity, Proceedings of the National Academy of Sciences of the United States of America, 106(27), 2009, 10933-10938.

[5]. P. Jain, Wind Energy Engineering ( $2^{\text {nd }} E d$.) (Mc Graw-Hill Education, 2016).

[6]. N. Argaw, Renewable Energy Water Pumping Systems Handbook (Denver, Colorado: NREL, 2004).

[7]. S. Eshita, A. Hossain, and M. Raihan, Design and Simulation of a Solar PV System for Brac University, (Brac University Bachelor, 2010).

[8]. H. Beheshti, Exploring Renewable Energy Policy in Lebanon, Master Thesis, American University of Beirut, Beirut, 2010.

[9]. X. Dawtec, Solar Insolation Level in Lebanon, Technical data, 2013.

[10]. J. D. Raj and M. Danis, Advanced Power Control Techniques for Hybrid WindPower Generation System Used in Standalone Application, International Journal of Power Control and Computation, vol. V, no. 2, May 2013, 610.

[11]. M. Zeman, Photovoltaic Systems, (Delft University of Technology, 2013).

[12]. G. Cipriani, V. Di Dio, A. Marcotulli and R. Miceli, Manufacturing Tolerances Effects on PV Array Energy Production, 3rd International Conference on Renewable Energy Research and Applications, Milwaukee, USA, Oct. 2014, 1-6.

[13]. S. Wenham, M. Green, M. Watt and R. Corkish, Applied Photovoltaics, (Earthscan, $2^{\text {nd }}$ Edition, Earthscan, 2007).

[14]. R. Kassis, P. El-Khoury, Wind Power in Lebanon; the Blades are Finally Turning!" Country Energy Efficiency and Renewable
Energy Demonstration Study, CEDRO Report, Issue 3, Lebanon, January 2013.

[15]. Z. Huaying, Wind Power Generator Co., (Technical report, Ltd, May, 2016).

[16]. A. Kaabeche, M. Belhamel, and R. Ibtiouen, Optimal sizing method for standalone hybrid PV/wind power generation system, Revue des Energies Renouvelables, Bou Is mail Tipaza Algeria, 2010, 205-213.

[17]. I. A. Adejumobi, S. G. Oyagbinrin, F. G. Akinboro, and M. B. Olajide, Hybrid Solar and Wind Power: an Essential for Information Communication Technology Infrastructure and People in Rural Communities, IJRRAS, vol. IX, no. 1, Oct. 2011, 130-138.

[18]. G. Halasa and J. A. Asumadu, Wind-solar hybrid electrical power production to support national grid: Case study - Jordan, IEEE 6th International Power Electronics and Motion Control Conference, Wuhan, 2009, 903-909.

[19]. Électricité Du Liban EDL, Public establishment Report, February 2015

[20]. R. Rawat, Simulation and Optimization of Solar Photovoltaic-Wind standalone Hybrid system in Hilly Terrain of India, International Journal of Renewable Energy Research, vol. III, no. 3, Feb. 2016, 596604.

[21]. J. D. Sorensen and J. Sorensen, Wind Energy Systems: Optimizing Design and Construction for Safe and Reliable Operation, (Elsevier, $1^{\text {st }}$ Ed ition, 2010).

[22]. S. Mishra, H. Koduvere, and I. Palu, Modelling of solar-wind hybrid renewable energy system architectures, IEEE International Energy Conference (ENERGYCON),Leuven Belgium, 2016, 16.

[23]. A. Shiroudi, G. Gharehpetian, A. Mousavifar, and A. A. Foroud, Case study: Simulation and optimization of photovoltaic-wind-battery hybrid energy system in Taleghan-Iran using HOMER software, Journal of Renewable and Sustainable Energy, no. 4, Sep. 2012, 1-11.

[24]. L. El Sayed, W. Sayegh, E. Saliba, and J. Stephan, Fossil Fuel Subsidies in Lebanon: Fiscal, Equity, Economic and Environmental Impacts, CCCU, UNDP Report, Lebanon 2015.

[25]. C. Federico and G. Lorca, Kipor KDE6700ta-KI Silent, 5KVA Diesel Generator, Solar Electrical Installations Co., Ltd, April, 2016. 